Lentera Pustaka: Jurnal Kajian Ilmu Perpustakaan, Informasi dan Kearsipan, 4 (2):89-100, 2018 Copyright (O2018, ISSN: 2302-4666 print/ 2540-9638 online

Available Online at: http://ejournal.undip.ac.id/index.php/lpustaka

\title{
Analisis Kualitas Perangkat Lunak Senayan Library Management System Versi 8 Akasia sebagai Sistem Otomasi Perpustakaan
}

\author{
Muhammad Rosyihan Hendrawan ${ }^{1 *}$

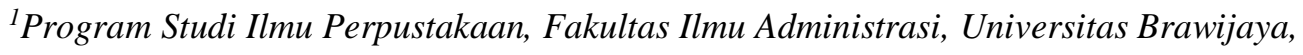 \\ Jl. MT. Haryono 163 Kota Malang, Indonesia. \\ ${ }^{*}$ Korespondensi: mrhendrawan@ub.ac.id
}

\begin{abstract}
[Title: The Analysis of Senayan Library Management System Version 8th] The open source-based library software users are currently growing rapidly in Indonesia. Therefore institutions or individuals who will use a software for library automation systems, must first know and understand the quality of the software which also includes deficiencies and their advantages so that they can be developed according to needs. This study aims to describe the quality of the Akayan Library Management System software version 8 (SLiMS Version 8 Akasia) as a library automation system. This study uses a qualitative approach with descriptive method. Data collection techniques use documentation and observation (testing / simulation). The results of this study, concluded that the quality of Akasia SLiMS V 8 software is appropriate when used as a library automation system. This is based on an analysis of the quality aspects of the software proposed by McCall. In the analysis of each aspect there are several weaknesses and strengths that support the software quality assessment standards that have been established in this research.
\end{abstract}

Keywords: Software quality; Open source; Information systems; Library automation

\begin{abstract}
Abstrak
Pengguna perangkat lunak perpustakaan yang berbasis open source saat ini sedang berkembang pesat di Indonesia. Oleh karena itu lembaga atau individu yang akan menggunakan sebuah perangkat lunak untuk sistem otomasi perpustakaan, terlebih dahulu harus mengetahui dan memahami kualitas perangkat lunak tersebut yang juga meliputi kekurangan beserta kelebihannya supaya dapat dikembangkan sesuai dengan kebutuhan. Penelitian ini bertujuan untuk mendeskripsikan kualitas Perangkat Lunak Senayan Library Management System versi 8 Akasia (SLiMS Versi 8 Akasia) sebagai sistem otomasi perpustakaan. Metode dalam penelitian ini menggunakan pendekatan kualitatif dengan jenis penelitian deskriptif. Teknik pengumpulan data menggunakan dokumentasi dan observasi (pengujian/simulasi). Hasil penelitian ini, menyimpulkan bahwa kualitas perangkat lunak SLiMS V 8 Akasia sesuai bila digunakan sebagai sistem otomasi perpustakaan. Hal ini didasarkan pada analisis aspek-aspek kualitas perangkat lunak yang dikemukakan McCall. Pada analisis setiap aspek terdapat beberapa kelemahan dan kelebihan yang mendukung standar penilaian kualitas perangkat lunak yang sudah ditetapkan pada penelitian ini.
\end{abstract}

Kata kunci: Kualitas perangkat lunak; Open source; Sistem informasi; Otomasi perpustakaan

\section{Pendahuluan}

Otomasi Perpustakaan adalah penggunaan perangkat komputer dengan menggunakan sistem untuk melakukan layanan perpustakaan (Patil, 2013: 2), sejalan dengan hal tersebut itu Pendit (2008: 20) mendefinisikan otomasi perpustakaan sebagai perangkat lunak komputer untuk kegiatan di perpustakaan yang terutama bercirikan penggunaan pangkalan data ukuran besar, dengan kandungan cantuman tekstual yang dominan, dan dengan fasilitas utama dalam hal menyimpan, menemukan, dan menyajikan informasi. Dalam siklus perkembangan teknologi informasi berbasis web sendiri, pangkalan data sangat 
dibutuhkan karena merupakan komponen penting dari sistem informasi di samping sebagai penentu kualitas informasi (O’Brien, 2010: 56).

Dalam siklus perkembangannya, peran perangkat lunak dalam sistem otomasi perpustakaan ternyata sangat besar dalam aktivitas pengelolaannya. Dari segi pendistribusian perangkat lunak, terdapat berbagai cara dalam mendapatkan perangkat lunak otomasi perpustakaan mulai dari membeli, membangun sendiri hingga menggunakan perangkat lunak open source. Menurut Boss (2008: 15) open source merupakan sebuah istilah yang digunakan untuk perangkat lunak gratis termasuk kode asli pemrograman (source code), sehingga pengguna dapat memodifikasi dan membuat berjalan lebih baik untuk kebutuhnnya. Termasuk didalamnya hak untuk mendistribusikannya (Dass and Chatterje 2015: $4)$.

Kemunculan perangkat lunak open source telah membuat momentum tidak hanya di negara maju namun juga di negara berkembang (Tyagi and Shentil, 2015: 414). Pengguna perangkat lunak perpustakaan yang berbasis open source pun saat ini sedang berkembang pesat di Indonesia. Oleh karena itu lembaga atau individu yang akan menggunakan sebuah perangkat lunak untuk sistem otomasi, terlebih dahulu harus mengetahui dan memahami kualitas perangkat lunak tersebut yang juga meliputi kekurangan beserta kelebihannya supaya dapat dikembangkan sesuai dengan kebutuhannya. Contoh perangkat lunak otomasi perpustakaan adalah Senayan Library Management System (SLiMS) Versi 8 Akasia yang dikembangkan oleh SLiMS Developer Community (SDC). Perangkat lunak yang dikembangkan secara internal organisasi atau lembaga tentu membutuhkan dana yang sesuai, dengan mendapatkan dukungan penuh dari pihak pengembang (developer) dalam hal ini SDC mulai dari instalasi hingga perawatan (maintenance).

Keandalan dan keakuratan perangkat lunak pun dapat dipertanggungjawabkan oleh pengembang. Perangkat lunak SLiMS Versi 8 Akasia merupakan perangkat lunak otomasi perpustakaan berbasis web dan open source. Seperti yang ditegaskan oleh Tabusum et al. (2013: 215) dan Wilson (2009: 27) perangkat lunak yang baik dalam mendukung suatu sistem otomasi adalah perangkat lunak yang berkualitas atau dengan kata lain perangkat lunak yang mampu memenuhi kebutuhan pengguna perangkat lunak itu sendiri. Menurut Pressman (2008: 34) dan Tyagi et al (2009: 13) kualitas adalah karakteristik pencapaian atas sebuah produk yang memenuhi atau melebihi persyaratan yang telah disetujui-diukur dengan kriteria dan alat ukur yang telah disepakati dan diproduksi dengan proses yang juga telah disetujui. Pencapaian kualitas tidak sesederhana tentang masalah pemenuhan persyaratan atau sebuah hasil yang memenuhi kebutuhan dan harapan pengguna, bahwa kualitas sebagai sebuah karakteristik atau atribut dari sesuatu. Sebagai atribut dari sesuatu, kualitas mengacu pada karaktristik yang dapat diukur-sesuatu yang dapat kita bandingkan dengan standar yang sudah diketahui, seperti panjang, warna, sifat kelistrikan dan sebagainya. Tetapi perangkat lunak yang sebagian besar merupakan entitas intelektual, lebih menantang untuk dikarakterisasi dari pada objek fisik (Patel and Patel, 2012: 94 ; Ayre, 2015: 43). Kualitas perangkat lunak adalah gabungan yang kompleks dari berbagai faktor yang akan bervariasi pada aplikasi dan pelanggan yang berbeda yang membutuhkannya 
(Pressman, 2008: 20) dan Ahmad (2015: 3).

Kemampuan perangkat lunak memenuhi kebutuhan pengguna yang dijadikan sebagai parameter penilaian kualitas sebuah perangkat lunak, digunakan oleh McCall dan kawan-kawan dalam teori kualitas perangkat lunak. McCall dan kawan-kawan menggunakan pertanyaan tentang tingkat kemampuan perangkat lunak memenuhi kebutuhan pemakai sebagai aspek pertama penilaian kualitas perangkat lunak. Atas dasar inilah peneliti memilih menggunakan teori yang dikemukakan oleh McCall dan kawan-kawan untuk menilai kualitas perangkat lunak SLiMS Versi 8 Akasia. Selain itu teori ini banyak digunakan sebagai dasar untuk melakukan analisis terhadap kualitas perangkat lunak. McCall dalam Pressman (2008: 32) mengusulkan kategorisasi yang berguna mengenai aspek-aspek yang mempengaruhi kualitas perangkat lunak yang berfokus pada tiga aspek produk perangkat lunak, antara lain: karakteristik operasionalnya, kemampuannya untuk mengalami perubahan, dan kemampuan untuk beradaptasi dengan lingkungan yang baru. Dengan mengacu pada tiga hal tersebut, McCall memberikan gambaran sebagai berikut: (1) Kebenaran, yaitu kemampuan perangkat lunak dalam memenuhi spesifikasi dan memenuhi sasaran misi pengguna (kebutuhan sistem otomasi di perpustakaan). (2) Reliabilitas, yaitu tingkat dimana sebuah perangkat lunak dapat melakukan fungsi yang diharapkan dengan ketelitian yang diminta. (3) Efisiensi, yaitu sumber daya komputasi yang dibutuhkan oleh perangkat lunak untuk melakukan fungsinya. (4) Integritas, yaitu tingkat kemampuan kontrol akses ke perangkat lunak atau data oleh orang yang tidak berhak. (5) Usabilitas, yaitu usaha yang dibutuhkan untuk mempelajari, mengoperasikan, menyiapkan input, dan menginterpretasikan output suatu perangkat lunak. (6) Maintainabilitas, yaitu kemampuan dan usaha yang diperlukan untuk membetulkan kesalahan pada sebuah program. (7) Fleksibilitas, yaitu kemampuan perangkat lunak untuk memodifikasi program operasional. (8) Testabilitas, yaitu kemampuan yang diperlukan untuk menguji dan untuk memastikan perangkat lunak telah melakukan fungsi-fungsi yang dimaksudkan. (9) Portabilitas, yaitu kemampuan yang dimiliki perangkat lunak untuk migrasi dari suatu perangkat lunak ke aplikasi atau lingkungan sistem aplikasi yang lain (platform komputasi). (10) Reusabilitas, yaitu kemampuan suatu perangkat lunak untuk dipergunakan ulang pada aplikasi lain. (11) Interoperabilitas, yaitu kemampuan aplikasi untuk dikonversikan atau migrasi ke perangkat lunak yang lain.

Kemampuan perangkat lunak untuk memenuhi kebutuhan pengguna merupakan aspek penting dalam kualitas perangkat lunak. Hal ini disebabkan karena sebaik apapun perangkat lunak apakah itu mudah digunakan dan memiliki kinerja yang bagus, perangkat lunak tidak akan memiliki arti ketika tidak mampu memenuhi kebutuhan pemakai. Kegagalan implementasi sistem otomasi perpustakaan yang kebanyakan terjadi disebabkan karena perangkat lunak yang tidak mampu memenuhi kebutuhan perpustakaan. Berdasarkan pada uraian di atas, lalu muncul pertanyaan apakah perangkat lunak SLiMS Versi 8 Akasia memiliki kualitas yang baik sebagai perangkat lunak untuk sistem otomasi di perpustakaan? Jika dikaitkan dengan jenis perangkat lunaknya yang merupakan open source, perkembangannya yang cepat dan selalu dalam pengembangan, serta masih dalam kondisi stabil akan tetapi ternyata aplikasi ini banyak pula institusi yang menggunakannya. Selain itu bagaimanakah 
kualitas perangkat lunak tersebut? Inilah sisi ketertarikan peneliti untuk mengkaji dan meneliti mengenai kualitas perangkat lunak SLiMS Versi 8 Akasia.

Maka dari itu dalam penelitian ini, peneliti memandang perlu untuk melakukan penelitian mengenai analisis kualitas perangkat lunak SLiMS Versi 8 Akasia yang dikembangkan oleh SLiMS Developer Community (SDC) sebagai sistem otomasi perpustakaan. Harapannya hasil penelitian ini dikemudian hari dapat dijadikan referensi bagi pustakawan dalam menentukan apakah perangkat lunak SLiMS Versi 8 Akasia memiliki kualitas baik atau tidak untuk digunakan oleh perpustakaan sebagai sistem otomasi perpustakaan.

\section{Metode Penelitian}

Penelitian ini menggunakan jenis penelitian deskriptif dengan pendekatan kualitatif. Pendekatan penelitian kualitatif bertujuan untuk menemukan pola hubungan yang bersifat interaktif, menemukan teori, menggambarkan realitas yang kompleks, dan memperoleh pemahaman makna (Sugiyono, 2014: 23). Lebih lanjut mengenai studi analisis, Arikunto (2010:30) menyebutkan bahwa studi ini bertujuan untuk menggali makna objek yang diteliti sesuai dengan pemahaman yang didapatkan. Langkah awal yang dilakukan peneliti adalah mengamati dan mencari informasi mengenai kebutuhan apa saja yang mendukung sistem otomasi di perpustakaan. Dengan dasar itulah nantinya akan diketahui apakah kualitas perangkat lunak SLiMS Versi 8 Akasia yang digunakan sudah mampu dalam mendukung sistem otomasi di perpustakaan atau belum. Kemudian langkah selanjutnya peneliti mempelajari dan menganalisis berbagai hal yang terkait dengan objek permasalahan penelitian. Fokus penelitian dimaksudkan untuk membatasi suatu masalah, dengan demikian fokus dari penelitian ini adalah aspekaspek yang mempengaruhi kualitas perangkat lunak menurut McCall dalam Pressman (2008: 32).

Untuk memperoleh data yang valid dan relevan dalam penelitian ini, maka peneliti menggunakan metode pengumpulan data sebagaimana pendekatan penelitian yang digunakan adalah observasi dan ulasan dokumen. Analisis data dalam penelitian ini disesuaikan dengan pendekatan penelitian yaitu pendekatan penelitian kualitatif.

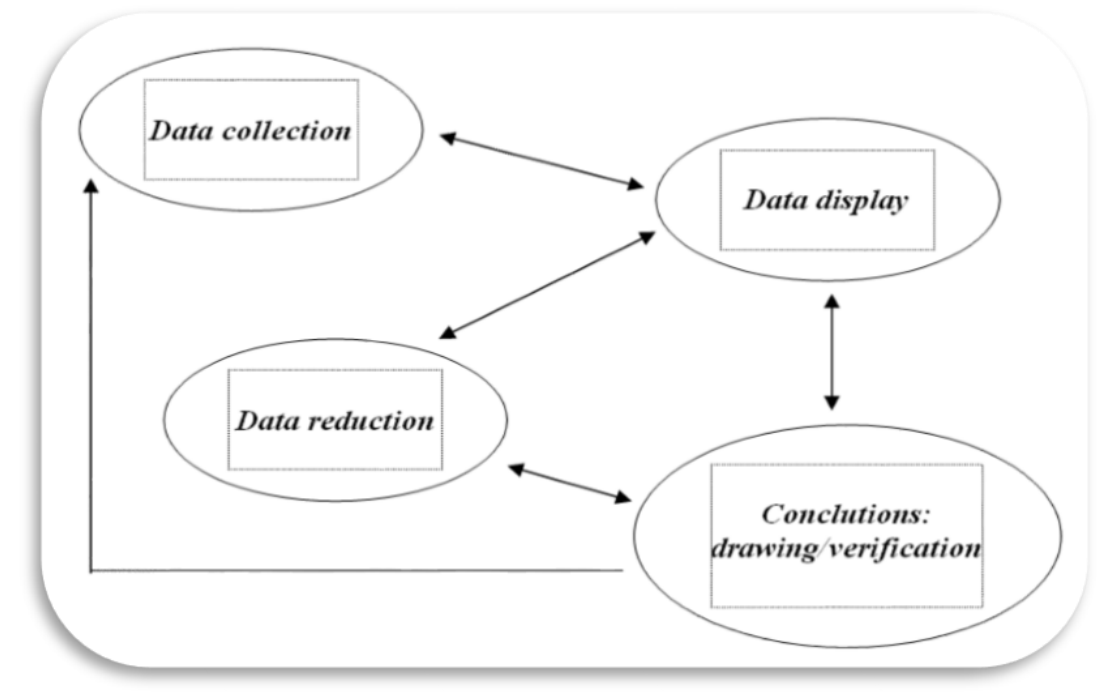


Gambar 1. Analisis Model Interaktif (Miles, Huberman dan Saldana, 2014: 33)

Adapun analisis data yang digunakan dalam penelitian ini adalah analisis data model interaktif Miles, Huberman dan Saldana (2014: 33), dimana analisis data model interaktif ini terdapat empat alur yang terjadi secara bersamaan

\section{Hasil dan Pembahasan}

SLiMS Versi 8 Akasia yang merupakan perangkat lunak otomasi perpustakaan berbasis web memiliki berbagai fitur penunjang kebutuhan yang terdapat di dalamnya. Berikut adalah fitur penunjang yang terdapat pada SLiMS Versi 8 Akasia yaitu : (a) Online Public Access Catalog (OPAC) dengan pembuatan thumbnail yang di-generate on-thefly. (b) Thumbnail berguna untuk menampilkan cover buku. (c) Mode penelusuran tersedia dalam bentuk sederhana (Simple Search) dan tingkat lanjut (Advanced Search). (d) Detail record (cantuman) juga tersedia format Extensible Markup Language (XML) untuk kebutuhan web service. (e) Manajemen data bibliografi yang efsien meminimalisasi redundansi data. (f) Manajemen master file untuk data referensial seperti Tipe Koleksi, Penerbit, Pengarang, Lokasi, Supplier, dan lain-lain.

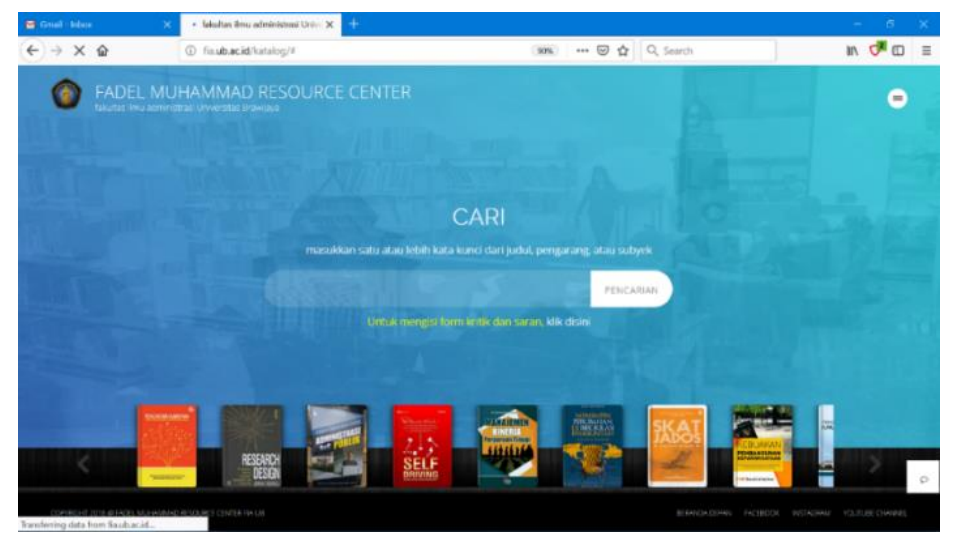

Gambar 2. Halaman Beranda Perangkat Lunak Otomasi Perpustakaan SLiMS versi 8 Akasia (SDC, 2018)

\subsection{Analisis Kualitas SLiMS Versi 8 Akasia}

Untuk mengetahui kualitas perangkat lunak SLiMS Versi 8 Akasia peneliti melakukan pengamatan atau observasi, pengetesan atau uji coba serta mengulas dokumen terkait. Berdasarkan hasil yang diperoleh dari analisis dari perangkat lunak SLiMS Versi 8 Akasia sebagai berikut :

a. Aspek kebenaran : pada aspek ini peneliti menemukan bahwa fasilitas yang disediakan perangkat lunak SLiMS Versi 8 Akasia, telah terdapat menu dan fitur aktif terkait penelusuran (OPAC), sirkulasi, manajemen bibliografi, pengadaan, laporan, inventarisasi, dan keanggotaan telah memenuhi misi dan spesifikasi kebutuhan standar sistem otomasi perpustakaan.
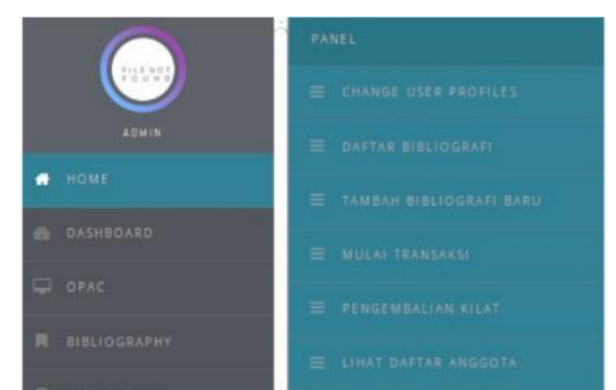
Gambar 3. Fasilitas pada Perangkat Lunak SLiMS versi 8 Akasia sesuai kebutuhan otomasi perpustakaan (Dokumentasi Peneliti, 2018)

b. Reliabilitas : pada aspek ini peneliti menemukan bahwa seluruh menu dan fasilitas yang disediakan perangkat lunak. Tidak muncul pernyataan "error" ketika menggunakan menu serta fasilitas yang disediakan dan semua menu pada Perangkat Lunak SLiMS versi 8 Akasia mampu berjalan sempurna.

c. Efisiensi : pada aspek ini peneliti menemukan bahwa dari sistem operasi yang digunakan mempengaruhi perangkat lunak melakukan fungsinya dengan baik, serta dapat diketahui versi minimal aplikasi pendukung dan utama yang digunakan agar perangkat lunak dapat melakukan fungsinya dengan baik.. Misalnya jenis aplikasi web server Apache, Bahasa pemrograman PhP dan Aplikasi Database MySqL

d.

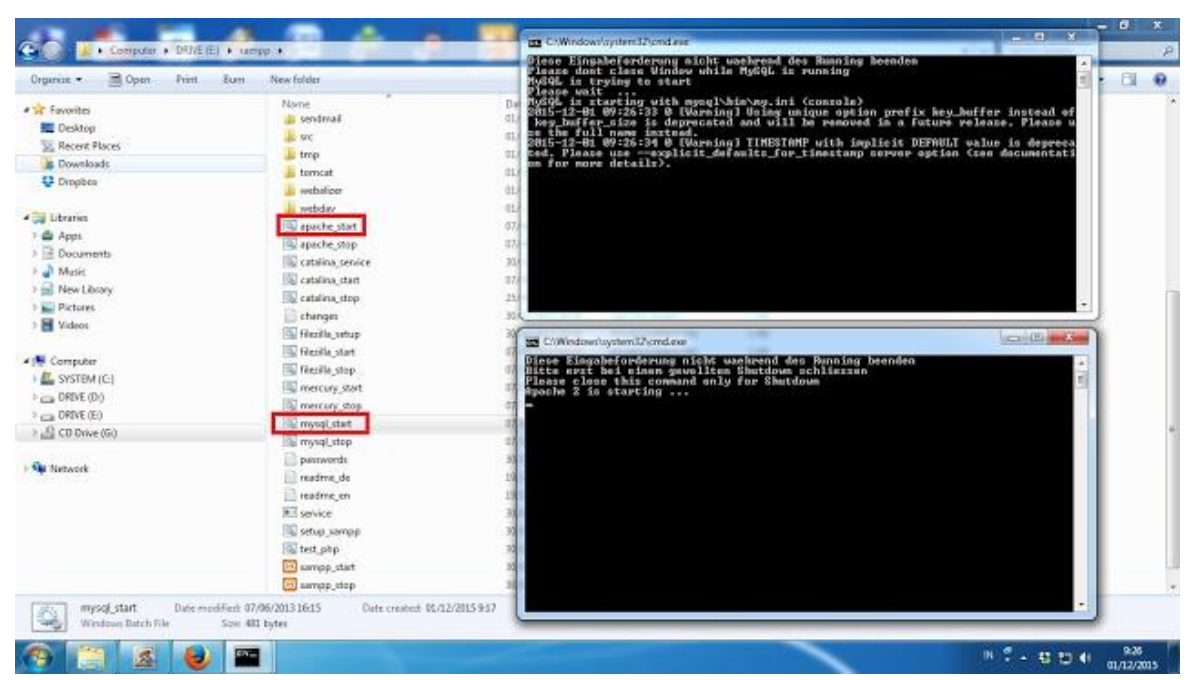

Gambar 4. Perangkat Lunak SLiMS versi 8 Akasia menjalankan Web Server Apache dan Bahasa Pemrograman PHP dengan baik pada proses Instalasi (Dokumentasi Peneliti, 2018)

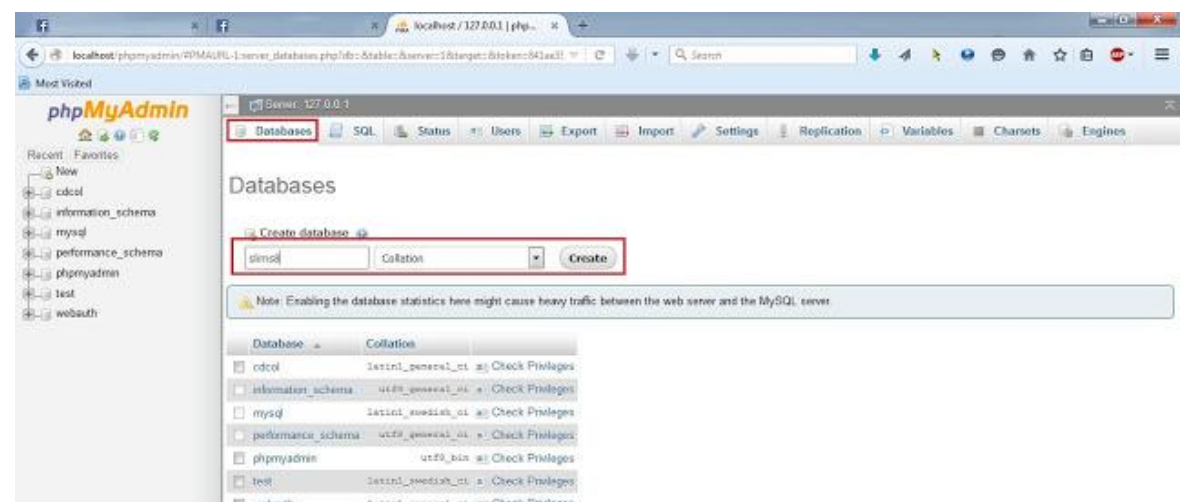


Gambar 5. Perangkat Lunak SLiMS versi 8 Akasia menjalankan Aplikasi Database MySql dengan baik pada proses Instalasi (Dokumentasi Peneliti, 2018)

Jenis aplikasi bahasa pemrograman yang dibutuhkan serta versi minimal agar perangkat lunak mampu melaksanakna fungsinya. Aplikasi database yang diperlukan serta versi minimalnya agar perangkat lunak melakukan fungsinya dan kebutuhan minimal RAM komputer perangkat lunak sehingga mampu menjalankan fungsinya dengan baik dan yang terakhir pada aspek ini peneliti menemukan bahwa terdapat kebutuhan minimal prosesor komputer yang dibutuhkan sehingga perangkat lunak mampu menjalankan fungsinya dengan baik.

e. Integritas : pada aspek ini peneliti menemukan bahwa pada halaman depan terdapat ketersediaan fasilitas login, sehingga kmungkinan administrasi untuk melalui menu login terlebih dahulu. Selain itu pemberian hak akses kepada pengguna biasa atau pengelola. Begitu pula fungsi menu keanggotaan beserta fasilitas yang disediakan, dan terdapat tingkat keamanan data dan hak akses ke dalam database.
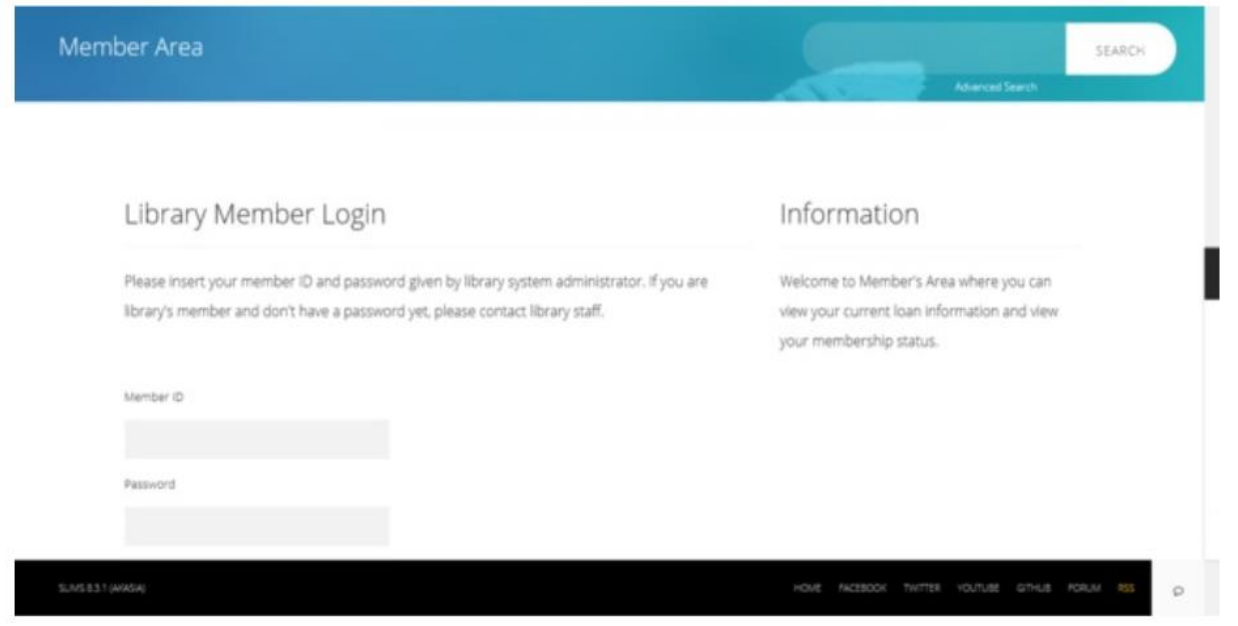

Gambar 6. Fasilitas Login pada Halaman depan Perangkat Lunak SLiMS versi 8 Akasia (Dokumentasi Peneliti, 2018)

f. Usabilitas : pada aspek ini peneliti menemukan bahwa ketersediaan komunitas yang secara aktif berpartisipasi dalam pelaporan bug dan memberikan masukan untuk pengembangan. Ketersediaan dokumentasi, pengetahuan yang diperoleh dari mempelajari, tingkat kesulitan dalam memahami baik sebelum ataupun setelah membaca modul dan panduan instalasi yang diperbaharui sesuai 
dengan versi Perangkat Lunak SLiMS. Dijelaskan juga pada modul tterkait keterampilan yang harus dimiliki untuk dapat mengoperasikan perangkat lunak.

g. Maintainabilitas : pada aspek ini peneliti menemukan bahwa menu dan sub menu yang disediakan perangkat lunak, peneliti melakukan percobaan dan pengetesan seluruh menu dan sub menu pada SLiMS Versi 8 Akasia. Kemudian dalam Usaha yang dilakukan untuk melakukan perbaikan perangkat lunak yaitu Developer SLiMS dari versi sebelumnya telah melakukan perbaikan script pada perangkat lunak serta pemeriksaan versi web server, database dan PHP.

h. Fleksibilitas : pada aspek ini peneliti menemukan bahwa menu dan fasilitas yang baru yang mungkin ditambahkan pada perangkat lunak SLiMS Versi 8 Akasia. Peluang untuk menambahkan menu dan fasilitas baru serta perubahan seperti apa yang terjadi pada program sangat didukung oleh sifatnya yang open source.

i. Testabilitas : pada aspek ini peneliti menemukan bahwa hasil percobaan menjalankan versi minimal Apache web server, MySQL, PHP yang memungkinkan program berjalan sempurna. Disamping itu peneliti melakukan percobaan terhadap seluruh menu dan sub menu yang terdapat pada perangkat lunak.

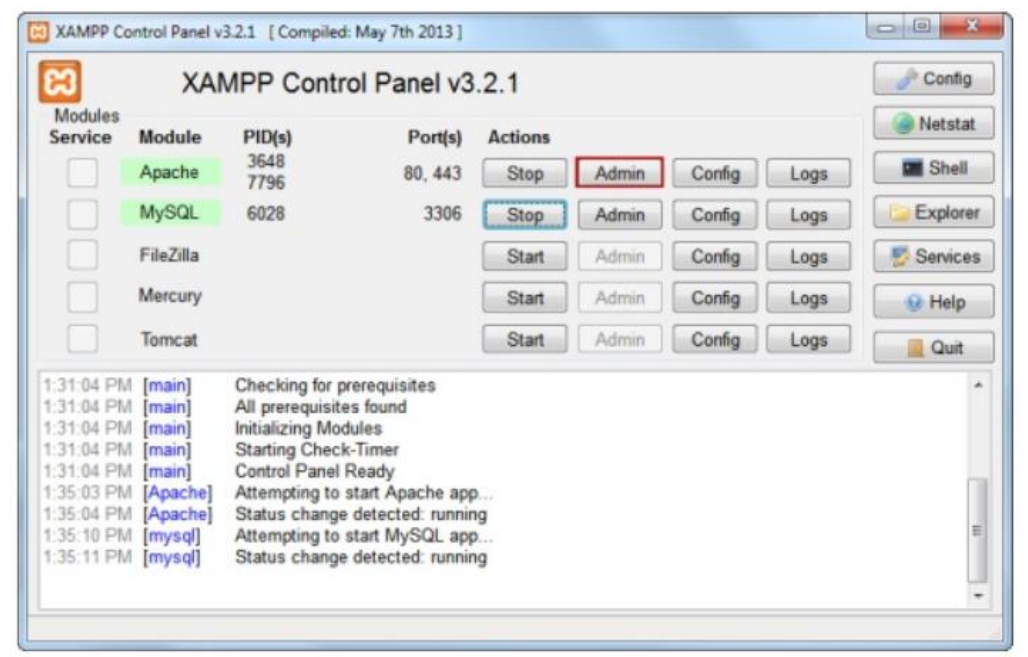

Gambar 7. Percobaan versi minimal Apache web server, MySQL, PHP memungkinkan Perangkat Lunak SLiMS versi 8 Akasia berjalan sempurna (Dokumentasi Peneliti, 2018)

j. Portabilitas : pada aspek ini peneliti menemukan bahwa pada prangkat lunak SLiMS Versi 8 Akasia sangat memungkinkan diinstalasi pada Sistem Operasi Windows, peneliti berhasil menginstal pada Sistem Operasi Windows 7 yaitu salah satu versi Windows yang memungkinkan perangkat lunak mampu berjalan sempurna. 


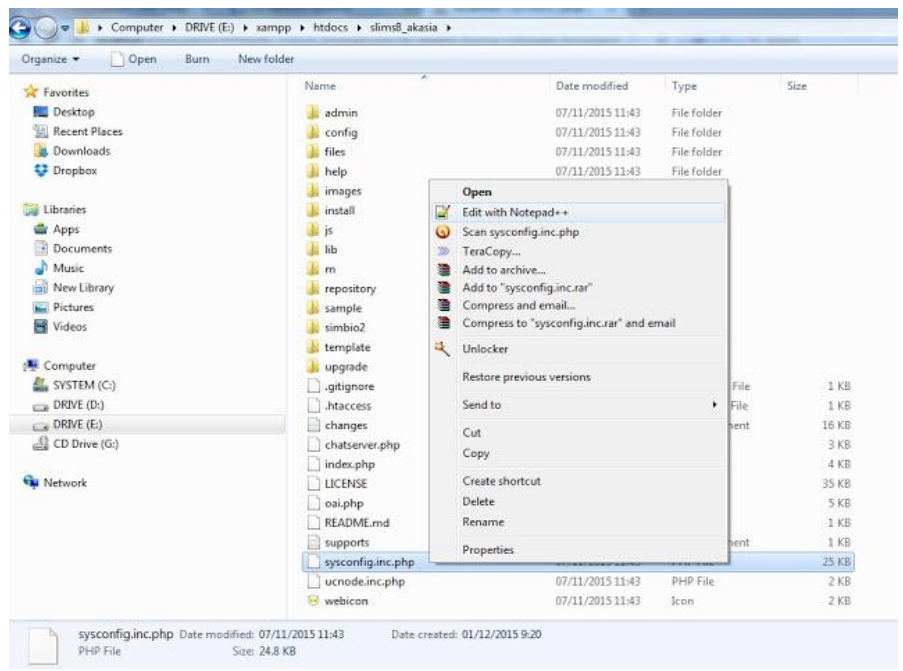

Gambar 8 Proses instalasi perangkat lunak SLiMS Versi 8 Akasia pada Sistem Operasi Windows 7 (Dokumentasi Peneliti, 2018)

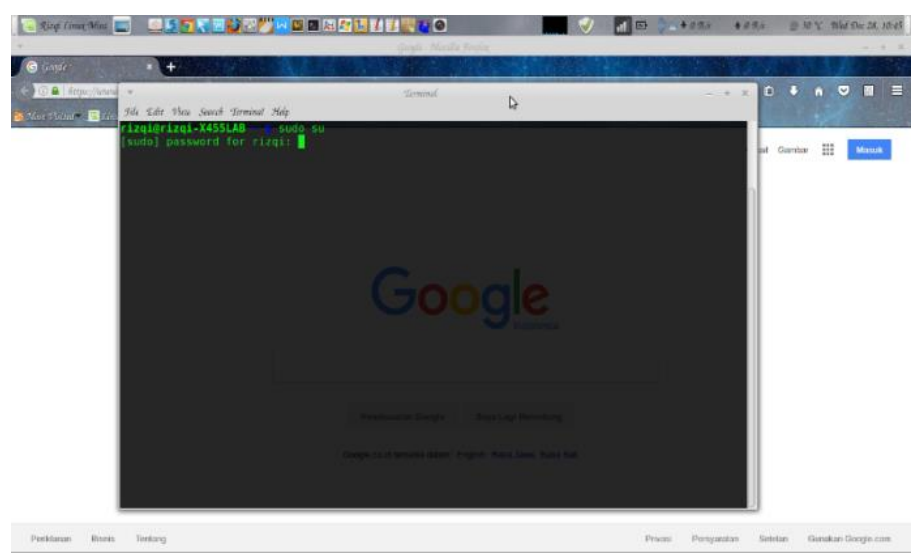

Gambar 9 Proses instalasi perangkat lunak SLiMS Versi 8 Akasia pada Sistem Linux Mint (Dokumentasi Peneliti, 2018) 
Kemudian peneliti melakukan instalasi pada Sistem Operasi Linux Versi Mint, versi Sistem Operasi tersebut juga memungkinkan perangkat lunak SLiMS Versi 8 Akasia mampu berjalan sempurna.

k. Reusabilitas : pada aspek ini peneliti menemukan bahwa ketersediaan perangkat lunak yang mampu mempergunakan perangkat lunak sebagai perangkat lunak tambahan. Perangkat lunak yang mampu menggunakan SLiMS Versi 8 Akasia sebagai perangkat lunak tambahan serta manfaat yang diperoleh setelah melakukan penggabungan SLiMS Versi 8 Akasia dengan perangkat lunak tersebut.

1. Interoperabilitas : pada aspek ini peneliti menemukan bahwa SLiMS Versi 8 Akasia mendukung akses ke perangkat lunak lain. Kemampuan penggabungan SLiMS Versi 8 Akasia dengan perangkat lunak lain serta bagaimana tingkat kesulitan proses penggabungan tersebut.

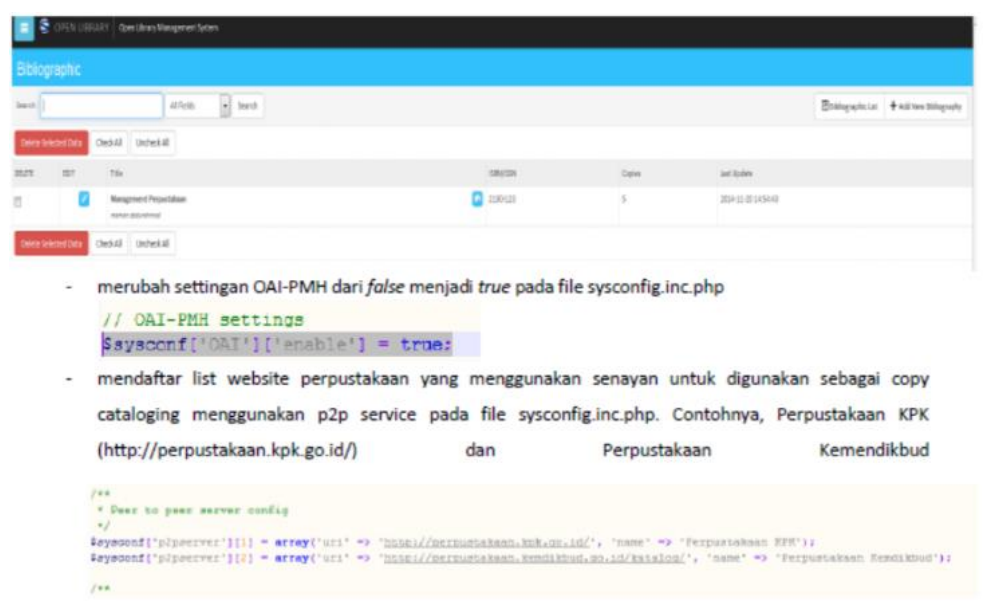

Gambar 10 Proses setting interoperabilitas perangkat lunak SLiMS Versi 8 Akasia

(Dokumentasi Peneliti, 2018)

Interoperabilitas adalah kemampuan berbagai ragam sistem atau aplikasi untuk bekerja sama dan bisa berinteraksi dengan aplikasi lainnya yang berbeda untuk memungkinkan terjadinya pertukaran data/informasi melalui suatu protokol yang disetujui bersama, lewat bermacam-macam jalur komunikasi, biasanya lewat network TCP/IP dan protokol HTTP dengan memanfaatkan file XML SLiMS Versi 8 Akasia yang telah dilengkapi dengan fitur open archive initiative (OAI-PMH) OAI$\mathrm{PMH}$.

\section{Simpulan}

Berdasarkan hasil analisis data yang telah dilakukan, maka dapat disimpulkan bahwa Kualitas perangkat lunak SLiMS Versi 8 Akasia telah memenuhi spesifikasi dan cakupan minimal sebagai perangkat lunak otomasi perpustakaan, walupun sesekali muncul pernyataan error pada saat menjalankan menu terlebih ketika proses instalasi karena terkait dengan berjalannya aplikasi 
pendukung. Fitur baru sangat memungkinkan untuk ditambahkan dan modifikasi mudah dilakukan terlebih didukung didukung dengan sifat open source perangkat lunak SLiMS Versi 8 Akasia.

Perangkat lunak SLiMS Versi 8 Akasia tidak membutuhkan spesifikasi komputer yang terlalu tinggi sehingga dapat meminimalisasi biaya yang terlalu tinggi untuk memenuhi kebutuhan otomasi perpustakaan, begitu juga integritas perangkat lunak SLiMS Versi 8 Akasia sudah baik karena memiliki sistem kontrol berlapis yakni akses dengan pemberian username dan password saat login. Perangkat lunak ini juga terbukti mudah untuk dipelajari dan tidak mensyaratkan latar belakang pendidikan tertentu, terlebih terdapat komunitas yang mendukung perkembangannya. Perangkat lunak SLiMS Versi 8 Akasia memiliki peluang yang besar untuk dihubungkan atau integrasikan ulang pada aplikasi yang lain walaupun agak rumit, dikarenakan pengguna harus memiliki pengetahuan tertentu dalam hal interoperabilitas.

\section{Daftar Pustaka}

Ahmad, Sufian. 2015. "Library Automation: A Case Study of DIHRM Library, New Delhi." IJNGLT, $\begin{array}{llllll}\text { August, } & \text { Vol } & 1 & \text { Issue } & 3 . & \text { Dalam }\end{array}$ http://www.ijnglt.com/files/Issue\%203/Revised\%20Article\%20(Library\%20Automation).pdf . tanggal 2 Oktober 2018 pukul 08.00 WIB

Arikunto, Suharsimi. 2010. Manajemen Penelitian. Jakarta: Rineka Cipta.

Ayre, Lori Bowen. 2015. "The Holy Grail of Library Automation: The Shared Library System," Collaborative Librarianship, Vol. 7, Issue 1, Article 9. Dalam at:https://digitalcommons.du.edu/collaborativelibrarianship/vol7/iss1/9. tanggal 2 Oktober 2018 pukul 09.00 WIB

Boss, Richard W. 2008. The Library Administrator's Automation Handbook. USA : Information Today Inc.

Das, Debasis and Chatterjee, Parnab. 2015. "Library Automation: an Overview." International Journal of Research in Library Science Volume 1 Issue 1. Dalam http://www.ijrls.in/wpcontent/uploads/2015/07/Library-Automation.pdf. tanggal 1 Oktober 2018 pukul 07.00 WIB

Miles, Matthew B., A. Michael Huberman and Johnny Saldana. 2014. Qualitative Data Analysis : A Methods Sourcebook $3^{\text {rd }}$ Ed. USA: Sage Publishing.

O’Brien, James. 2010. Pengantar Sistem Informasi: Perspektif Bisnis dan Manajerial. Jakarta: Salemba Empat.

Patel, Pravin I and Patel Bipinchandra A. 2012. "Library automation planing.” PARIPEX - Indian Journal of Research, Vol.1, Issue 12 pp 90-96. Dalam https://www.worldwidejournals.com/paripex tanggal 29 Juli 2018 pukul 02.00 WIB

Patil, V. 2013. "Library automation and networking: Need and importance of maharashtra public libraries." Journal of Advances in Library and Information Science, 2, 152-156. Dalam www.jalis.in, tanggal 29 Juli 2018 pukul 02.00 WIB

Pendit, Putu Laxman. 2008. Perpustakaan Digital dari A sampai Z. Jakarta: Citra Karyakarsa Mandiri. 
Pressman, Roger. 2008. Rekayasa Perangkat Lunak: Pendekatan Praktisi (Buku I). Yogyakarta: Andi.

SLiMS Developer Community (SDC). 2018. "Pengguna Perangkat Lunak SLiMS." Dalam http://slims.web.id, tanggal 11 Juli 2018 pukul 12.00 WIB.

Sugiyono. 2014. Metode Penelitian Kuantitatif, Kualitatif Dan R\&D. Bandung: Alfabeta.

Tabusum, Shabana, Saleem, A and Batcha, M. Sadik. 2013. "Impact of Library Automation in the Development Era." OSR Journal Of Humanities And Social Science Vol. 17, Issue 5, pp 20-26. Dalam http://iosrjournals.org/iosr-jhss/papers/Vol17-issue5/D01752026.pdf. tanggal 03 September 2018 pukul 13.00 WIB.

Tyagi, A.K. and Senthil, V. 2015. "Library Automation in India: Assessment of Library Services Platforms." DESIDOC Journal of Library \& Information Technology, Vol. 35, No. 6, November 2015, pp. 408-416.

Tyagi, A.K.; Raghuraman, A.; Dhanwantri, M. and Kalbhor, P. 2009. "Improving visibility of libraries through SRU.” DESIDOC Journal of Library \& Information Technology, Vol. 29, No. 3, 12-15, pp $10-17$.

Wilson, Tom 2009. "Evaluation Strategies for Library and Information Systems." Dalam http:// information.net, tanggal 03 September 2018 pukul 18.47 WIB. 